\title{
Charismatic Leadership and Creativity: An Empirical Investigation in China
}

\author{
Hongchun HU, Yang LIU \& Bingsheng YAN \\ Staff Development Institute of China National Tobacco Corporation, Zhengzhou, Henan, China
}

\begin{abstract}
This article aims to explore the effect of charismatic leadership on creativity. By using survey data from 314 employees of a large tobacco company in China, we found that charismatic leadership was positively related to follower creativity, psychological ownership mediated the effect of charismatic leadership on creativity, and coworker helping and support moderated the relationship between charismatic leadership and creativity. Theoretical and practical implications are discussed.
\end{abstract}

KEYWORD: Charismatic leadership; Creativity; Psychological ownership; Coworker helping and support

\section{INTRODCTION}

Considerable evidence suggests that employee creativity can substantially contribute to organizational innovation, effectiveness, and survival (Zhang \& Bartol, 2010). A growing body of studies have focused on identifying contextual factors and management practices that influence creativity in organizations (Shalley \& Zhou, 2008). Several studies explored the relationship between leadership and creativity (Jung et al.,1999). Prior work on leadership and creativity has predominantly centered on the relationship between leader behaviors and employee creativity (Sternberg \& Vroom, 2002). Recently, researchers have investigated broader leadership behavior theories, such as charismatic leadership (House, et al., 1991). However, only a few studies have examined the effects of charismatic leadership on followers' creativity. This study aims to explore the connection between charismatic leadership and creativity combined with several important and influential factors. We accomplish this goal through the following steps: First, we investigate the relationship between charismatic leadership and creativity. Second, we test whether psychological ownership mediated this relationship. Third, we test whether coworker helping and support moderated this relationship.

\section{THEORY AND HYPOTHESES}

\subsection{Charismatic leadership and creativity}

The concept of charismatic leadership is a prominent representative of new theories that have been emerging in leadership research in the last two decades (Dvir et al. 2002). Charismatic leadership is defined as "the ability of a leader to exercise diffuse and intense influence over the beliefs, values, behavior, and performance of others through his or her own behavior, beliefs, and personal example" (House et al., 1991). In recent years, leadership scholars have paid attention to the role of charismatic leadership in enhancing factors that affect individual and organizational effectiveness, such as employee mood, organizational citizenship behaviors and performance (Tsai et al., 2009), and organizational financial performance (Campbell et al., 2008). Hence, the topic of charismatic leadership remains worth exploring in organizational studies.

In contrast to traditional leadership theories that emphasize rational processes, charismatic leadership theory concentrates on emotions and values, and acknowledges the importance of symbolic behavior and the role of the leader in making events meaningful for followers (House, et al., 1991). Charismatic leadership enhances creativity in organizational settings in several ways. First, charismatic leaders promote followers' creativity by articulating an idealized vision, which emphasizes desired future states (Locke \& Kirkpatrick, 1995). Second, charismatic leaders promote creativity through creative role models. Followers admire and respect these charismatic leaders, which is why they are willing to engage in creative behaviors to emulate them (Jaussi \& Dionne, 2003). Third, charismatic leaders promote followers' creativity by articulating high levels of optimism and confidence in the followers' ability to achieve future goals, 
because charismatic leadership relates positively to leader visions that build confidence and optimism (Berson, Shamir, Avolio, \& Popper, 2001). Therefore, followers believe that they have the confidence and optimism to cope with any risk in creative processes. Therefore, we expect that

H1. Charismatic leadership will be positively related to followers' creativity.

\subsection{Mediating role of psychological ownership}

Psychological ownership is defined as individual feelings toward substantial or non-substantial things (Pierce et al., 2001). Pierce et al. (2004) argued that individuals who recognize comparative privileges are the same individuals who sense and commit psychological ownership.

Several studies highlight the association between leadership and creativity (Zhang \& Bartol, 2010). However, little is known about the link between charismatic leadership and creativity. This study aims to explores the potential role of psychological ownership as a mediating factor; we concentrate on creativity. Charismatic leadership enhances psychological ownership in organizational settings through several ways (Pierce et al., 2003). In the present study, we followed other investigators (e.g., Judge \& Piccolo, 2004) in examining charismatic leadership as a unitary construct.

Existing theory (Pierce et al., 2001) suggests that psychological ownership is related to a number of important organizational outcomes, such as feelings of responsibility, stewardship, and so on. With the target of ownership being increasingly brought into the citadel of the self, individuals take on responsibility for the owned object and focuses on related matters and takes them seriously (Pierce et al., 2001), which motivates them to participate in the improvement process (Fuller, et al., 2006). We expect to find that psychological ownership has a mediating effect on the relationship between charismatic leadership and creativity by combining the leadership style's proposed effect on psychological ownership and the psychological ownership's antecedent effect on creativity. Thus,

H2. Psychological ownership mediates the relationship between charismatic leadership and creativity.

\subsection{The moderating role of coworker helping and support}

Creativity research has shown that organizational contextual factors and practices can have a significant role in facilitating or inhibiting employee creativity (Shalley \& Zhou, 2008). Coworkers may provide a stimulating environment for creativity through help and support (Zhou \& Geogre, 2001). In the present study, coworker helping and support refers to the degree of assistance enacted by work colleagues (Liao, Joshi, \& Chuang, 2004). We contend that coworker helping and support is a contextual factor that likely plays a key role in determining whether charismatic leadership actually translates into enhanced creativity.

Creativity involves coming up with new ideas and new ways of doing things but also entails certain risks (Zhou \& Geogre, 2001). Help and support from coworkers may protect the focal employee from negative consequences (Brewer, 1991). The employee may also acquire knowledge and expertise from coworkers, which may make creating new ways of doing things possible (Woodman et al., 1993). As described earlier, the employee may believe that creativity is likely to be effective when he or she is surrounded by coworkers who are able and willing to share expertise and provide encouragement-with the help of coworkers, useful new ideas are likely to be generated, heard, and successfully implemented (Farr \& Ford, 1990). Thus,

H3: Coworker helping and support moderates the relationship between charismatic leadership and creativity in such a way that charismatic leadership has a stronger positive relationship with creativity for followers who gain or have access to extensive Coworker helping and support, compared with followers who do not have their coworkers' help and support.

Based on the preceding analyses, this study constructs the research model.

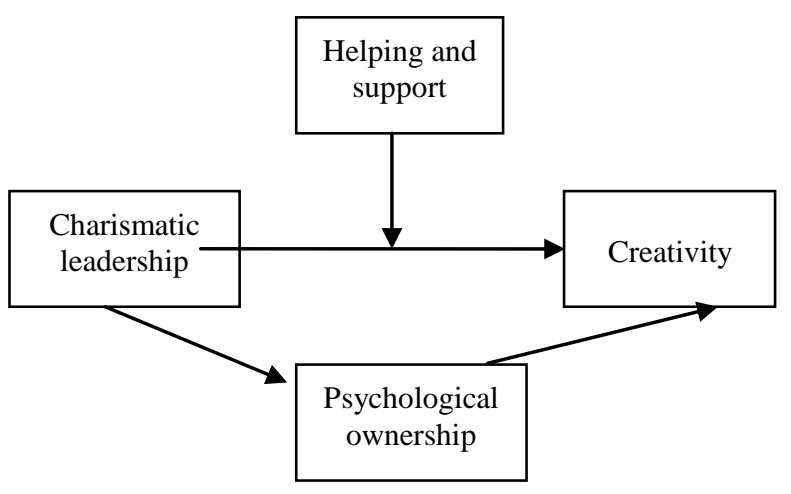

Figure 1. Research Model

\section{METHOD}

\subsection{Data collection}

Data were obtained from the headquarters of a tobacco company in China. The participants were the majority of the employees, including engineers and administrators, whose work requires substantial creativity to be effective. By using contact information obtained from the company's human resources department, we sent an e-mail with a link to an online survey to 423 professional employees. The employees also received an e-mail from the 
company's vice president, who encouraged them to support and participate in the study.

A total of 314 questionnaires were completed and returned, which indicates a response rate of $74.2 \%$. About $84.4 \%$ of the respondents were below 25 years old, and $15.6 \%$ were above 25 years old. The average tenure was 5.31 years. Among the 314 respondents, $84.7 \%$ were male; $71.3 \%$ hold bachelor's degrees and $28.7 \%$ do not.

\subsection{Measurement}

Charismatic leadership. We used a seven-item scale that was adopted from the charisma subscale of the Multi-Factor Leadership Questionnaire (MLQ) (Bass $\&$ Avolio, 1990) to measure charismatic leadership. Members of each group were asked to rate the designated leader of their groups based on the MLQ items by using a six-point scale. The Cronbach's $\alpha$ for this scale was 0.93 .

Employee creativity was assessed by using a fouritem self-evaluation developed by Tierney, Farmer, and Graen (1999) on a six-point scale. This creativity scale taps actions perceived by participants in our exploratory research to reflect the Chinese view of employee creativity. The Cronbach's $\alpha$ for this scale was 0.91 .

Psychological ownership was measured by using a three-item scale adapted from Pierce et al. (2001) on a six-point scale. Measurement items include, "I feel this company is MINE," "I feel closely involved in the success or failure of the company," and "I am willing to treat my company as my home." The Cronbach's $\alpha$ for this scale was 0.80 .

Help and support items were adapted from Podsakoff, Ahearne, and MacKenzie (1997). Employees indicated the extent to which each of the three statements applied to their coworkers. The Cronbach's $\alpha$ for this scale was 0.78 .

Control variables. Accounting for sample heterogeneity, we controlled age, gender, education, and tenure, which distinguish employee creativity (Tierney \& Farmer, 2002) and are related to team processes (Edmondson, 1999). We measured age (below $25=1$, from 25 to $30=2$, above $30=3$ ), gender (male $=1$; female $=2$ ), education (below/college diploma $=1$; college degree $=2$; above/college degree $=3$ ), and tenure (in number of years). We also controlled for organizational commitment. Five items $(\alpha=0.70)$ were adapted from their six-point scale. Examples of these items are "my goals are less aligned with those of my organization" (reverse scored) and "I feel a stronger sense of loyalty to the entire organization." The Cronbach's $\alpha$ for this scale was 0.90 .

\section{ANALYSIS}

Result suggests that creativity is significantly and positively correlated with charismatic leadership $(\mathrm{r}=0.33, \mathrm{p}<0.01), \quad$ psychological ownership $(\mathrm{r}=0.26, \mathrm{p}<0.01)$, coworker helping and support $(\mathrm{r}=0.39, \mathrm{p}<0.01)$, and organizational commitment $(\mathrm{r}=0.31, \mathrm{p}<0.01)$. Charismatic leadership is significantly and positively correlated with psychological ownership $\quad(\mathrm{r}=0.36, \mathrm{p}<0.01)$ and coworker helping and support $(\mathrm{r}=0.54, \mathrm{p}<0.01)$. Coworker helping and support is significantly and positively correlated with organizational commitment $(\mathrm{r}=0.53, \mathrm{p}<0.01)$.

We conducted hierarchical regression analyses to test the hypotheses. Table 1 summarizes the regression results for testing $\mathrm{H} 1$, which states that charismatic leadership is positively related to follower creativity, and $\mathrm{H} 3$, which states that coworker helping and support moderates the relationship between charismatic leadership and creativity. In model 2, we regressed creativity on the control variables and charismatic leadership. In model 4, we withheld creativity on the controls, charismatic leadership, coworker helping and support, and the interaction between charismatic leadership and coworker helping and support. The results of model 2 show that charismatic leadership was statistically significant with creativity. Thus, H1 was supported. In support of $\mathrm{H} 3$, the results of model 4 indicate statistical significance of the change in the multiple squared correlation coefficient $(\Delta \mathrm{R} 2)$ associated with the interaction between charismatic leadership and coworker helping and support. which demonstrates that the hypothesized pattern of the two-way interaction applies (Aiken \& West, 1991).

Table 1 shows $\mathrm{H} 2$ test results, one of which posits the mediating role of psychological ownership. To test mediation, we followed the widely used procedure suggested by Baron and Kenny (1986). In model 1, we regressed psychological ownership on the control variables and charismatic leadership. In model 2, we regressed creativity on the same set of control and independent variables as entered in model 1 . In model 4 , we regressed creativity on the controls, charismatic leadership, and psychological ownership. The results supported $\mathrm{H} 2$ as follows: (1) Charismatic leadership was a statistically significant contributor to psychological ownership. Charismatic leadership was a significant contributor to creativity. (3) The psychological ownership regression coefficient was significant in contributing to creativity when we controlled the control variables and charismatic leadership. The statistically insignificant decrease of charismatic leadership's coefficient in model 3 indicated that psychological ownership fully mediated the contribution of charismatic leadership to followers' creativity. 
Table1: Results of Hierarchical Regression Analysis for Mediation and Moderation

\begin{tabular}{|l|c|c|c|c|}
\hline & $\begin{array}{c}\text { Model1: } \\
\text { ownership }\end{array}$ & $\begin{array}{c}\text { Model2: } \\
\text { creativity }\end{array}$ & $\begin{array}{c}\text { Model3: } \\
\text { creativity }\end{array}$ & $\begin{array}{c}\text { Mode4: } \\
\text { creativity }\end{array}$ \\
\hline Gender & 0.01 & -0.02 & 0.01 & -0.02 \\
\hline Year & $-0.09^{*}$ & -0.07 & -0.07 & -0.05 \\
\hline tenure & 0.10 & -0.01 & 0.02 & -0.02 \\
\hline Education & -0.11 & -0.04 & -0.04 & -0.02 \\
\hline $\begin{array}{l}\text { Organization } \\
\text { commitment }\end{array}$ & 0.12 & 0.16 & 0.07 & 0.14 \\
\hline $\begin{array}{l}\text { Charismatic } \\
\text { leadership }\end{array}$ & $0.28^{* * *}$ & $0.20^{*}$ & 0.11 & 0.16 \\
\hline $\begin{array}{l}\text { Psychological } \\
\text { ownership }\end{array}$ & & & & $0.16^{* *}$ \\
\hline Helping and support & & $0.33^{* * *}$ & \\
\hline $\begin{array}{l}\text { Charismatic } \\
\text { leadership } \times \text { Helping } \\
\text { and support }\end{array}$ & $10.28^{* * * *}$ & $7.01^{* * *}$ & $9.79^{* * *}$ & $7.14 * * *$ \\
\hline F & 0.17 & 0.12 & 0.20 & 0.14 \\
\hline R2 & 0.15 & 0.10 & 0.18 & 0.12 \\
\hline Adjusted R2 & $0.08^{* * *}$ & & $0.02^{* *}$ \\
\hline$\Delta$ R2 & & & & \\
\hline
\end{tabular}

$* \mathrm{p}<0.05, * * \mathrm{p}<0.01, * * * \mathrm{p}<0.001$

\section{DISCUSSION}

The first contribution of our study is that it identifies the positive effect of charismatic leadership on creativity in China. Although previous studies (Wang \& Rode, 2010) examined the effects of transformational leadership on creativity, however, few studies have attempted to directly examine the effect of charismatic leadership on creativity, especially in China. The second is that it identifies a psychological process by which charismatic leadership is related to creativity. In our study, psychological ownership mediated the effect of charismatic leadership on creativity. Third, in revealing the moderating role of coworker helping and support as one of social support. Our results suggest that perceived coworker support for creativity can play a positive role in channeling charismatic leadership into creativity.

From a practical standpoint, our findings suggest that managers can facilitate creativity by stimulating charismatic leadership. Moreover, as charismatic leadership predicts creativity through psychological ownership, organizations can influence psychological ownership by promoting a charismatic leadership style among leaders through selection and leadership development programs.

Our study has several limitations. First, data on all the major constructs were collected with selfreports from employees, which raises the possibility of same-source bias. Second, this study was conducted in one tobacco company, and the results might not be applicable in other contexts. Future work in other cultures can help verify the validity of our findings.

\section{REFERENCES}

[1] Bass, B.M.1985.Leadership and performance beyond expectations. Free Press, New York.

[2] Brewer. M. B. 1991.The social self: On being the same and different at the same time. Personality and Social Psychology Bulletin. 17, 475-482.

[3] Berson, Y., Shamir, B., Avolio, B.J., Popper, M. 2001.The relationship between vision strength, leadership style and context. Leadership Quarterly, 12, 53-73.

[4] Campbell, S. M., Ward, A., Sonnenfeld, J. A., Agle, B. R. 2008. Relational ties that bind: Leader-follower relationship dimensions and charismatic attribution. Leadership Quarterly, 19, 556-568.

[5] Dvir, T., Eden, D., Avolio, B.J., \& Shamir, B. 2002.Impact of transformational leadership on follower development and performance: A field experiment. Academy of Management Journal, 45, 735-744.

[6] Farr, J.L., \& Ford, C.M.1990.Individual innovation. In M. A. West \& J. L. Farr (Eds.), Innovation and creativity at work. New York, NY: John Wiley \& Sons.

[7] House, R.J., Spangler, W.D. and Woycke, J. 1991. Personality and charisma in the US presidency: a psychological theory of leader effectiveness, Administrative Science Quarterly, 36(3), pp. 364-396.

[8] Judge, T.A., \& Piccolo, R.F. 2004.Transformational and transactional leadership: A meta-analytic test of their validity. Journal of Applied Psychology, 89, 755-768.

[9] Jung, D.I., \& Avolio, B.J. 1999.Effects of leadership style and followers' cultural orientation on performance in group and individual task conditions. Academy of Management Journal, 42, 208-218.

[10] Liao, H., Joshi, A., Chuang A. 2004. Sticking out like a sore thumb: Employee dissimilarity and deviance at work. Personnel Psychology,57, 969-1000.

[11] Pierce, J. L., Kostova, T., \& Dirks, K. T. 2001.Toward a theory of psychological ownership in organizations. Academy of Management Review, 26, 298-310.

[12] Shalley, C. E., \& Zhou, J. 2008. Organizational creativity research: A historical overview. In J. Zhou \& C. E. Shalley (Eds.), Handbook of organizational creativity: 95123. New York: Taylor and Francis.

[13] Sternberg, R.J.,\& Vroom, V .H. 2002.The person versus the situation in leadership. Leadership Quarterly, 13, 301323.

[14] Tierney, P.,\& Farmer, S.M.1999.The Pygmalion process and employee creativity. Journal of Management, 30:413432.

[15] Tsai, W., Chen, H. Cheng, J.2009.Employee positive moods as a mediator linking transformational leadership and employee work outcomes. The International Journal of Human Resource Management, 20, 206-219.

[16] Wang, P., \&Rode, J.C.2010.Transformational leadership and follower creativity: The moderating effects of identification with leader and organizational climate. Human Relations, 63(8):1105-1128.

[17] Woodman,R., Sawyer, J., \& Griffin, R.1993.Toward a theory of organizational creativity. Academy of Management Review, 8: 293-321.

[18] Zhou, J. 2003. When the presence of creative coworkers is related to creativity: Role of supervisor close monitoring, developmental feedback, and creative personality. Journal of Applied Psychology, 88, 413-422. 